The University of Akron

\title{
IdeaExchange@UAkron
}

January 2016

\section{From Transaction to Interaction: Socio-materiality, Reliability and Transparency in an Age of "Unbound Documents"}

Christopher W. Colwell

University of Technology, Sydney, Christopher.Colwell@uts.edu.au

Please take a moment to share how this work helps you through this survey. Your feedback will be important as we plan further development of our repository.

Follow this and additional works at: https://ideaexchange.uakron.edu/docam

Part of the Archival Science Commons

\section{Recommended Citation}

Colwell, Christopher W. (2015) "From Transaction to Interaction: Socio-materiality, Reliability and Transparency in an Age of "Unbound Documents"," Proceedings from the Document Academy: Vol. 2 : Iss. 1 , Article 18. DOI: https://doi.org/10.35492/docam/2/1/18

Available at: https://ideaexchange.uakron.edu/docam/vol2/iss1/18

This Conference Proceeding is brought to you for free and open access by University of Akron Press Managed at IdeaExchange@UAkron, the institutional repository of The University of Akron in Akron, Ohio, USA. It has been accepted for inclusion in Proceedings from the Document Academy by an authorized administrator of

IdeaExchange@UAkron.For more information, please contact mjon@uakron.edu, uapress@uakron.edu. 


\section{Introduction}

Recordkeeping professionals influence, mediate and constrain behaviour by providing the environment, systems, processes, tools and advice for the staff in the organisations in which they work to effectively create, capture and manage records (Bailey \& Vidyarthi, 2010). This is done in accordance with best practice or legislative requirements but also in accordance with the organisational risk appetite, tolerance and funding for these activities. Recordkeeping professionals in effect serve three masters - the organisation, the relevant legislative or best practice recordkeeping requirements within which they operate, as well as their users or records creators.

Without the active and ongoing engagement of the records creators within organisations, the archives of tomorrow will be full of "digital dust" (Evans, 2015). However, few existing studies have records creators and users, records and their interrelationships in "originating agencies" (Foscarini, 2013), even though the recordkeeping profession has long argued for the need for "a more sophisticated view of organizational processes" (Yakel, 1996, p. 454). Current approaches to recordkeeping tend to ignore the complex human element and follow 'hard systems' approaches that dominate our management and systems thinking (Foscarini, 2010).

This study, and the larger doctoral study of which it is a part, explores the perspectives held by officials from different disciplinary backgrounds on records in Australian Government agencies during this time of digital transition in order to provide practitioners and archival authorities with a more sophisticated understanding of the socially constructed nature of records and the practices and discourses which shape them.

This paper explores themes emerging from a case study which suggest that organisational processes and the socio-material nature of social media may affect how users construct their concepts around records and the transparency and the reliability of records in an age of "unbounded documents". Some context on recordkeeping in the Australian Government is provided before going on to outline the theoretical model for the study, methodology, preliminary findings and concluding thoughts.

\section{Recordkeeping in the Australian Government}

Recordkeeping in the Australian Government takes place in a context of legislation and of contemporary practices and expectations. Thus it is seen that sound public administration relies on recording or documenting the business of government (Management Advisory Committee, 2007). Australian Government agencies, via their recordkeeping professionals, develop and implement recordkeeping frameworks to ensure that records are made, kept and available for accountability purposes, that records of continuing value are preserved and records no longer required are securely and accountably destroyed (Kennedy \& Schauder, 1998). In recent years Australian Government 
agencies have also been encouraged to "go where the crowd is" and engage in the use of social media for business purposes.

The requirements that Australian Government agencies need to meet for recordkeeping derive from legislation, policy and standards. Primary among these is the Archives Act 1983 (the Archives Act) which governs access to, preservation and destruction of information created and received when undertaking Australian Government business. Other requirements such as freedom of information, privacy and information security also apply across government.

The Archives Act defines a record as "a document, or an object, in any form (including any electronic form) that is, or has been, kept by reason of (a) any information or matter that it contains or that can be obtained from it; or (b) its connection with any event, person, circumstance or thing" ("Archives Act (Cth)," 1983). The Archives Act refers to the Acts Interpretation Act 1901 for the definition of document. This is defined as "any record of information, and includes: (a) anything on which there is writing; and (b) anything on which there are marks, figures, symbols or perforations having a meaning for persons qualified to interpret them; and (c) anything from which sounds, images or writings can be reproduced with or without the aid of anything else; and (d) a map, plan, drawing or photograph" .

Social media posts are then documents, but may also be records in an Australian Government context (National Archives of Australia, 2015). Unlike other documentary forms of records they exist outside the boundaries of the organisation to which they relate, and which created them. They are "unbound" from the usual organisational systems and processes of creation, management and control but still subject to relevant legislative and recordkeeping obligations. In their native format they exist outside the firewall, but yet may also have to be brought back inside the organisation and captured again to satisfy recordkeeping and accountability requirements (Hesling, 2014).

Recordkeeping professionals are "bound" by definitions of records in legislation, or that are widely adopted within the recordkeeping profession, that rely heavily on the concepts of transaction and evidence. It has been suggested that the evidential and transaction-based notions that underpin these definitions are limiting and may not be relevant in today's Web 2.0 world (Yeo, 2007, 2008) particularly since the importance of context and structure, two key concepts for the capture of authentic and reliable records, are diminished in this online environment (Bell, 2014).

Records creators and users are "unbound" from these constraints. Web 2.0 technologies which currently pervade our business environments and Open Government agendas are talked of in terms of facilitating interaction, not the transactions implied in the official definitions (Franks, 2009). The concept of interaction suggests people, participation and their relationships, implying a two-way exchange with information passed back and forth. Initial indications from this study suggest that interaction, in keeping with the Web 2.0 language, 
may be a more meaningful term to describe the context in which, and of which, records are kept to our users than the word transaction. It may also be a more suitable term for a digital world.

\section{Theoretical model}

Using contemporary practice theory as a lens, a reconceptualization of the Processes for Organisational Meanings (POM) model developed by Checkland and Holwell (1998) is being used as a theoretical model within which to explore the perceptions of records of diverse professional groups in Australian Government agencies.

The POM Model emanates from Soft Systems Methodology (SSM) and is a representation of the ongoing workplace interactions involved in meaning creation. It depicts the relationships between the organizational context in which individuals and groups create meanings, form intentions and take purposeful action with the aid of information systems. The foundation of the POM Model is discourse and the intersubjective creation of meaning (Checkland \& Holwell, 1998).

Models of recordkeeping have, until recently, privileged the object (i.e. the record) over the human elements of the practices, or worse ignored them altogether. While the Australian Government has a recordkeeping framework which adopts the Records Continuum Model (Upward, 1996, 1997, 2005), which acknowledges agents and objects as elements of recordkeeping practice, its interpretation and application has generally been narrowly applied ignoring the interrelated view of a practice as comprising both humans and non-humans.

The reconceptualization of the POM Model (Figure 1) shifts the focus from an 'object-centric' view to one which focusses on the individual, social and technological aspects of recordkeeping practices as equally important and related parts of the whole in a digital world. In this sense, recordkeeping practices are conceived of as 'temporally unfolding, materially mediated arrays of human activity centrally organized around shared practical understanding' (Schatzki, 2001, p. 2).

Like Checkland's original model, the adapted model maintains a focus on discourse and the intersubjective creation of meaning. Discursive practices regarding records and recordkeeping, like other practices, contain bodily patterns, routinized mental activities and objects that are linked to each other. When participating in discursive practices "participants ascribe, in a routinized way, certain meanings to certain objects (which thus become 'signs') to understand other objects, and above all, in order to do something" (Reckwitz, 2002).

After MacIntosh-Murray (2003), the adapted model incorporates the wider information and recordkeeping environment shown as a dotted line around the outside. For this study, this dotted line represents the continua and the dimensions of the Records Continuum, the theoretical framework for recordkeeping in the Australian Government. It is an acknowledgement that: 
- individuals, group members and members of organisations or professions participate intra and extra-organisationally as part of their 'networks of practice' (Brown \& Duguid, 1991);

- there is a diversity of actors, rules, things and institutions that form a part of the Australian Government recordkeeping environment within which all Australian Government agencies operate (the continua of the continuum); and

- recordkeeping in the Australian Government stretches from the everyday interactions with citizens as part of the business of government to the societal in the form of the preservation of the nation's cultural heritage (the dimensions of the continuum).

The primary adaptation though is around Element 7 - the information systems and authoring desktop technologies, including social media tools, used as part of organisational processes. The role of information technology in recordkeeping within organisational settings, like many other business processes, is generally only considered when a particular technology event occurs and is treated as a matter of one-off interest. This loses sight of the fact that all organisational practices are bound with materiality and that it is not incidental or intermittent but integral to it (Orlikowski 2007). 


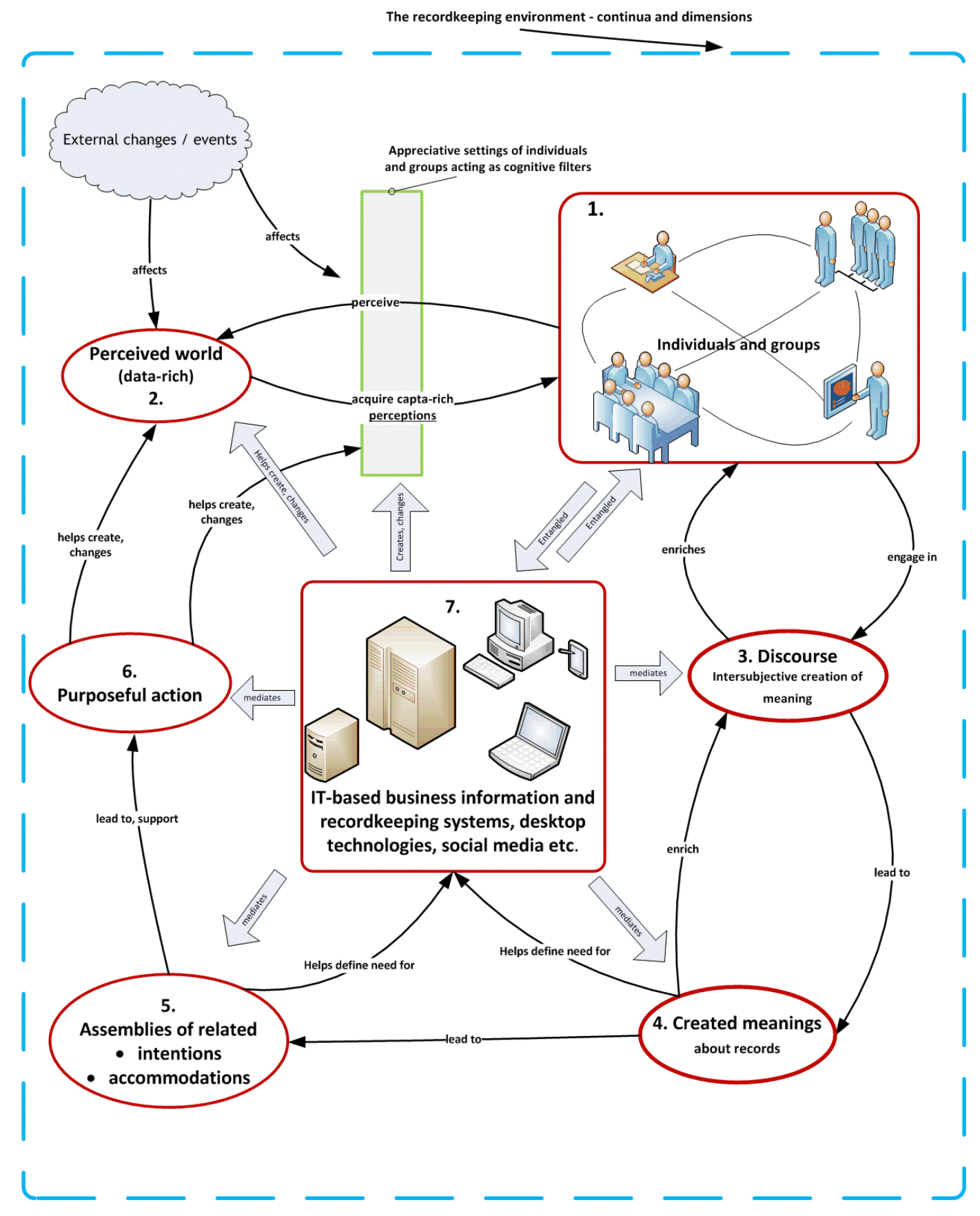

Figure 1 - Processes for organisational meanings as adapted from Checkland and Howell (1998)

Information technologies play a key role in enabling (or potentially constraining) recordkeeping and recordkeeping practices in a digital environment. In organisations most records are now 'born digital' and created via desk-top technologies and captured into recordkeeping systems. The centrality of these to recordkeeping and organisational practices is acknowledged by moving these information technologies and the records they contain to the centre of the adapted model. 
The adapted model, after Foscarini (2009) and her use of Adaptive Structuration Theory with SSM, extends this notion of the iterative interplay between agent and technology, to acknowledge the socio-material nature of practices around information systems and technologies and the records within those systems and technologies. Socio-materiality extends our thinking around records and recordkeeping systems by emphasising that they are not independent technical objects but are constituted in, and emerge from, the performance of social practices and at the same time configure those practices in particular ways (Doolin \& McLeod, 2012).

Agents and technology are then considered as constituting sociomaterial 'entanglements' (Orlikowski, 2007). The mediating arrows extending out from and to Element 7 represent these socio-material 'entanglements'(Orlikowski, 2007), which play an active role in mediating the discourse and interactions as part of meaning creation and may also potentially enable or constrain recordkeeping behaviours or change perceptions of records and recordkeeping.

\section{Methodology and methods}

In this case study-based research (Yin, 2014), which draws on an understanding of the context and the experiences of the individuals are required. (Darke \& Shanks, 2002), an in-depth semi-structured interview was the main data collection instrument and the theoretical model outlined above guided the selection of appropriate interview questions. A general inductive approach, similar to the use of induction in grounded theory, was utilised for analysis, with data being closely examined to identify themes and concepts, and the relationships between these being explored (Williamson, Burstein, \& McKemmish, 2002).

The findings outlined below represent those general themes and overall impressions from the interviews in the first case study that have emerged in the preliminary stages of analysis (Cresswell, 2009).

This case presented here is an Australia government statutory agency which has been working almost completely digitally in a document management and records management sense for approximately eight years. It has a social media presence on a number of platforms and most staff do not use hardcopy records in their daily work.

The staff responsible for recordkeeping and seven other professionals from different disciplines and areas of the business were interviewed. Each interview lasted approximately one hour. Where key themes have parallels with literature already reviewed, this has been noted below.

\section{Themes from the case study}

\section{Understanding the document}

A key theme that emerged from this case study was that there was no common definition of the document or record. Implicit practices in relation to 
recordkeeping were present in other disciplines, but only the person from the information technology discipline had explicit technical terminology regarding the terms 'record' and 'archive' and even then a distinction was made between 'record' as a technical IT term and a 'business record'. In this sense, participants in the study did not use 'bounded' definitions.

A document is not necessarily to be kept - it can be anything ... For the record, maybe there's more value to be kept for future reference. (Business user 3)

Any interaction I think that we have with a business particularly is an official record of a conversation with a business, whether you've provided any advice or they've asked you for something, or they've provided you information. (Business user 2)

Differences in definition, including those that reflect existing disciplinary schools of thought, have been noted in the literature (Finnell, 2011; Yeo, 2007; Yusof \& Chell, 1999).

The definition of record in the Archives Act and applicable international standards on recordkeeping were not helpful to staff in practical sense. This is because these definitions are so broad and principles-based that everything is or could be a record as the following responses show:

I mean for the average public servant, I don't think it's very meaningful (Business user 1)

From a day-to-day sort of practical implementation of information management, record-keeping practices, that definition sounds a little bit too legalistic and it probably doesn't mean a lot to individuals who are going to use this .. it sounds very broad-reaching. I guess pretty much anything. (IT professional)

However, staff found the definition in the Australian and International Standard (AS ISO 15489) ${ }^{1}$ slightly more useful.

I find that to be a little bit better. I mean, again, then you're still talking about the subjective and you're sort of like struggling. I mean as if I'm in a room, in the dark talking about what might constitute information. Do you know what I mean? (Digital marketing professional)

This theme mirrors some previous observations of the Australian Auditor-General when, in reviewing common themes in the Australian National Audit Office's reviews of recordkeeping in the Australian Public Service, he noted that most people would not find the definition of a record in the Archives Act "terribly helpful to determine what a record is from a practical perspective". He went on to note that even the definition in the Australian and International Standard "is quite a handful"(McPhee, 2007).

\footnotetext{
${ }^{1}$ Records are "information created, received, and maintained as evidence and information by an organization or person, in pursuance of legal obligations or in the transaction of business" (Standards Australia 2002).
} 
The definition of document used in the Acts Interpretation Act contains more in common with personal constructions of that concept.

I find that a bit more useful because that gives you the categories (Legal professional)

\section{Transactions and Interactions}

The term interaction was used by a number of the participants when describing their own definitions of records, whereas only one used the word transaction. Staff generally understood and appreciated the rationale for keeping records from a transactional perspective.

For the Australian government, it's risk mitigation. It's FOI. It's a corporate memory. It's learning what works and what doesn't. But it's also legal, as well. And also I think there's a personal responsibility and that's why we've got a code of conduct. (Digital marketing professional)

Those that had worked in the wider public service longer and those that had worked in Departments of State, generally had a better understanding of the transactional requirements of the policy and legislation. While staff did not really understand the details of the organisational recordkeeping policy, most understood the notion of a 'life cycle' in relation to records i.e. that most records would eventually be destroyed and some might become 'archives'.

Staff unanimously viewed all kinds of electronic media as records.

Content determines the value of what is to be kept or not, but the format, I treat all equally (Business user 3)

This result is interesting in itself as practitioners are often heard to complain that their staff don't understand that digital records are records too.

Trust in 'internal' records was high. In general, reflecting an interactional approach, so long as an internal person provided the information to them participants 'trusted' it.

It's a professional organisation... There is certain level of confidence that I take with my colleagues (Digital marketing professional)

This reliability or trust was not dependent on the type of record necessarily i.e. whether it was paper vs electronic or whether the document came from a shared drive (considered non-compliant in a recordkeeping sense) or whether it came from a formal document management system or even a business system.

Internally I would say paper vs digital or database or core business system, equally reliable ... it's all about the behaviours of the organisation ... I don't think one is less than the other. (HR professional)

This reflects themes in research conducted by Meijer (2003) which noted that external accountability bodies did not challenge or question the authenticity of documents provided by organisations which were stored in many kinds of organisational systems (compliant or not).

The exception to this was social media. Some staff did not see this as 'a reliable record', although most conceded that a post from their own agency 
would be considered as such. However more 'established' digital technologies, even those that were received from external parties or dynamic such as business systems, were accepted as records. Social media was outside the firewall, so not only was it not 'internal' it was also perceived in some cases as unreliable because of its format.

Some of the contemporary social media tools that have records attached to them are not perceived to be as authoritative as a signed letter or even if it's an electronic letter or an email...A tweet is just out there amongst thousands of tweets and those records are of lower value than something you can touch and feel and looks to have more intellectual robustness to it. (HR professional)

Two types of professional considered this differently, the agency's social media marketing professional and the staff responsible for recordkeeping.

Previous studies have found that social media sites are not neutral channels or mediators of content. The socio-material practices that constitute these social media sites are actively part of, and integral to, the relations enacted, the knowledge produced and the accountabilities that are considered significant (Feldman \& Orlikowski, 2011; Scott \& Orlikowski, 2009, 2012).

The use of multiple social media channels, and the socio-material practices surrounding them, are examples of how these practices might affect the knowledge produced, relations enacted and accountability and transparency of the agency. They exemplify interactions rather than transactions. Some of the social media channels use a combination of open and closed groups, and other channels are open to all. Some issues may be resolved quickly online and the answers form part of that site and others may need further research so are taken offline and out of their original context.

Participants in this study were aware that the business of the organization might be recorded in multiple media and on multiple platforms some internal and some external. To complicate matters, some participants recognised that a series of interactions may begin online in one media and then be resolved in another, so even an online interaction may have a clear definable starting point but in some cases no clear end.

In 140 characters we'll put it out factually and if there's a question then there's a decision gets made based on the matrix of, "Do we respond?" and then "Shall we take it offline or do we respond on the platform so that everyone can see?" (Digital marketing professional)

Social media and the interactive, evolving and experienced-based nature of the web are blurring the lines between what was once a simple and straightforward business transaction (using email, letter or even business to business transactions) and "interactions" which use Web 2.0 and other technologies, or those that at least begin there before transitioning to other more traditional digital technologies. As online e-Government services evolve to better meet the needs of consumers the volumes of these 'messy' interactions are expected to increase presenting even greater challenges for recordkeeping professionals (Bertot, 2015). 


\section{Conclusion and next steps}

The Australian Government is in a stage of Digital Transition, with the ultimate policy aim of having all information and records being managed digitally. If the future of Government is digital and online, there are indications from this study that the 'bounded' definitions used by practitioners and archival authorities are not helpful to end users and that a transactional approach is limiting. Considering records in the context of interactions, in keeping with the Web 2.0 language, may be a more meaningful way to describe the relationship which users have to organisational records than the word transaction. It may also be a more suitable term for a digital world.

This issue of the shift away from a bounded definition of 'record' and from a transactional approach to the record in the business of a government agency is significant for recordkeeping practices and warrants further study. Similarly, many questions, including those of co-creation, trust and trustworthiness of recordkeeping systems (in their broadest sense), must be explored in any move towards the 'unbounded' nature of an interactional approach to recordkeeping, regardless of whether it includes social media. 


\section{References}

Acts Interpretation Act (Cth), (1901).

Archives Act (Cth), (1983).

Bailey, S., \& Vidyarthi, J. (2010). Human-computer interaction: the missing piece of the records management puzzle? Records Management Journal, 20(3), 279-290.

Bell, A. R. (2014). Participation vs principle: does technological change marginalize recordkeeping theory? In C. Brown (Ed.), Archives and recordkeeping: theory into practice. London: Facet.

Bertot, J. (2015). eGovernment: implications for the archival sphere. Paper presented at the Archival Educators and Researchers Institute, University of Maryland.

Brown, J. S., \& Duguid, P. (1991). Organizational learning and communitiesof-practice: Toward a unified view of working, learning, and innovation. Organization science, 2(1), 40-57.

Checkland, P., \& Holwell, S. (1998). Information, systems and information systems: making sense of the field. Chichester: John Wiley and Sons.

Cresswell, J. W. (2009). Research design: qualitative, quantitative and mixed methods approaches (3rd ed.). Thousand Oaks, CA: Sage.

Darke, P., \& Shanks, G. (2002). Case study research. In K. Williamson (Ed.), Research methods for students, academics and professionals: information management and systems (2nd ed.). Wagga Wagga, NSW: Centre for Information Studies, Charles Sturt University.

Doolin, B., \& McLeod, L. (2012). Sociomateriality and boundary objects in information systems development. European Journal of Information Systems, 21(5), 570-586. doi:10.1057/ejis.2012.20

Evans, J. (2015, 13 July 2015). [Discussion session following presentation at the Archival Educators and Researchers Institute].

Feldman, M. S., \& Orlikowski, W. J. (2011). Theorizing practice and practicing theory. Organization science, 22(5), 1240-1253. doi:10.1287/orsc. 1100.0612

Finnell, J. (2011). Records management theory's dilemma: what is a record? Library Philosophy and Practice, 2011.

Foscarini, F. (2010). Understanding the context of records creation and use:'hard'versus 'soft'approaches to records management. Archival Science, 10(4), 389-407.

Foscarini, F. (2013). Records as social action: understanding organizational records through the lens of genre theory. Information Research, 18(3), Paper C08. Retrieved from http://InformationR.net/ir/183/colis/paperC08.html

Franks, P. C. (2009). Understanding Web 2.0 and the challenges for the Records Manager. Information and Records Management Annual, 2009, 107121.

Hesling, E. (2014). Records, social media and the right to access: the social media conundrum. Paper presented at the Records and Information 
Management Professionals Australasia National Conference, Adelaide, S.A.

Kennedy, J., \& Schauder, C. (1998). Records management : a guide to corporate record keeping (2nd ed.). South Melbourne, Vic.: Longman.

Management Advisory Committee. (2007). Note for File: a report on recordkeeping in the Australian Public Service. Retrieved from Canberra:

McPhee, I. (2007). An ANAO perspective of records in government. Paper presented at the National Archives of Australia Seminar CheckUp: Audit Issues and Electronic Records Solutions, Parliament House, Canberra.

Meijer, A. J. (2003). Trust This Document! ICTs, Authentic Records and Accountability. Archival Science, 3(3), 275-290.

National Archives of Australia. (2015). Social media: another type of Commonwealth record. Retrieved from http://www.naa.gov.au/recordsmanagement/agency/digital/socialmedia/index.aspx

Orlikowski, W. J. (2007). Sociomaterial practices: exploring technology at work. Organization Studies, 28(9), 1435-1448.

Reckwitz, A. (2002). Toward a theory of social practices: a development in culturalist theorizing. European journal of social theory, 5(2), 243-263.

Schatzki, T. R. (2001). Introduction: practice theory. In T. R. Schatzki, K. Knorr-Cetina, \& E. v. Savigny (Eds.), The practice turn in comporary theory (pp. 1-14). London: Routledge.

Scott, S. V., \& Orlikowski, W. J. (2009). 'Getting the truth': exploring the material grounds of institutional dynamics in social media. Paper presented at the 25th European Group for Organizational Studies Conference, Barcelona, Spain.

Scott, S. V., \& Orlikowski, W. J. (2012). Reconfiguring relations of accountability: Materialization of social media in the travel sector. Accounting, organizations and society, 37(1), 26-40.

Upward, F. (1996). Structuring the records continuum - part one: postcustodial principles and properties. Archives \& Manuscripts, 24(2), 268-285.

Upward, F. (1997). Structuring the records continuum - part two: structuration theory and recordkeeping. Archives \& Manuscripts, 25(1), 10-35.

Upward, F. (2005). The records continuum. In S. McKemmish, M. Piggot, B. Reed, \& F. Upward (Eds.), Archives: recordkeeping in society. Wagga Wagga, NSW: Centre for Information Studies, Charles Sturt University.

Williamson, K., Burstein, F., \& McKemmish, S. (2002). The two major traditions of research. In K. Williamson (Ed.), Research methods for students, academics and professionals: information management and systems (2nd ed.). Wagga Wagga, NSW: Centre for Information Studies, Charles Sturt University.

Yakel, E. (1996). The way things work: procedures, processes, and institutional records. American Archivist, 59(4), 454-464. 
Yeo, G. (2007). Concepts of Record (1): Evidence, Information, and Persistent Representations. American Archivist, 70(2), 315-343.

Yeo, G. (2008). Concepts of Record (2): Prototypes and Boundary Objects. American Archivist, 71(1), 118-143.

Yusof, Z. M., \& Chell, R. W. (1999). The eluding definitions of records and records management: is a universally acceptable definition possible?: part 1: defining the record. Records Management Journal, 8(2), 95-112. 